\title{
Optimization of Initial Folding Square Sections for the Crashworthiness Design
}

\author{
M Yoggaraj Muthusamy ${ }^{1)^{\star}}$, Kamaruddin $^{2)}$, Moch. Agus Choiron ${ }^{3)}$ \\ 1) Mechanical Engineering Department of University Tun Hussein onn Malaysia \\ ${ }^{2,3)}$ Mechanical Engineering Department of Brawijaya University
}

doi: 10.24843/JEM.2018.v11.i01.p06

\begin{abstract}
In this study, crash behavior of optimization of initial folding square sections are evaluated. Three parameters of design are set as width $(\mathrm{w})$, height $(\mathrm{h})$ and thickness $(\mathrm{t})$ with three levels. Deformation mode of crash box and energy absorbing due to frontal load is observed. Response surface method is used to optimize the Initial folding square sections. Box-Bhenken is chosen to provide this setting and 13 models is built. Computer simulation is used to determine the energy absorption by using Software Finite Element Analysis. Based on computer simulation results, it can be denoted that $\mathrm{w}=1.1 \mathrm{~mm}, \mathrm{~h}=0.9 \mathrm{~mm}$ and $\mathrm{t}=2.75 \mathrm{~mm}$ produce the highest of energy absorption.
\end{abstract}

Keywords: Initial folding, RSM, Square section, Energy absorption, Deformation mode

\section{Introduction}

Safety place an important role in the designing modern vehicles [1]. Generally when vehicles collides with another object, the structure that collapse to absorb the impact energy for the safety of the passengers are called crash box [2]. The crash box particularly designed for absorption of the energy during the impact [3]. In the previous studies many researchers have been paid considerable attention to improve crashworthiness of crash box. In the thin wall members of crash box the kinetic energy is dissipated by progressive deformation at collision and minimum amount of force transferred to the occupants [4]. There have been numerous researches carried out on initial folding sections development technique to produce more folding and the crushing behavior were observed under axial impact [5]. Crash box with holes is designed to create as prefolding corresponds with peak crush force reducing [6]. Square section of crash box become more intension to enhance the energy absorption performance. In this study, initial folding square sections is investigated.

\section{Methodology}

Computer simulation is used to determine the energy absorption of $130 \mathrm{~mm}$ length crash box with three square-initial folding by using ANSYS Rel. 17.0. Three parameters of design are set as width ( $w)$, height $(\mathrm{h})$ and thickness ( $\mathrm{t}$ ) with three levels as shown in Table 1 and Fig. 1. Response surface method is used to optimize the Initial folding square sections. Box-Benhken is chosen to provide this setting and 13 models is built as shown in Table 2 .

The crash box model component are impactor and crash box as shown in Fig. 2. Material aluminum 6063-T5 was used in this study as shown in the Table 3. Impactor velocity is $7.67 \mathrm{~m} / \mathrm{s}$ and the maximum deform occurs until $73 \mathrm{~mm}$.
Table 1. Three levels of parameters

\begin{tabular}{|l|c|c|c|}
\hline & Level -1 & Level 0 & Level 1 \\
\hline Width (w) & 0.9 & 1 & 1.1 \\
\hline Height (h) & 0.9 & 1 & 1.1 \\
\hline Thickness (t) & 2.25 & 2.5 & 2.75 \\
\hline
\end{tabular}

Table 2. Box-Bhenken Setting

\begin{tabular}{|l|l|l|l|}
\hline Model & $\begin{array}{l}\text { Thickness } \\
(\mathrm{mm})\end{array}$ & $\begin{array}{l}\text { Width } \\
(\mathrm{mm})\end{array}$ & $\begin{array}{l}\text { Height } \\
(\mathrm{mm})\end{array}$ \\
\hline 1 & 2.5 & 1 & 1 \\
\hline 2 & 2.25 & 0.9 & 1 \\
\hline 3 & 2.75 & 0.9 & 1 \\
\hline 4 & 2.25 & 1.1 & 1 \\
\hline 5 & 2.75 & 1.1 & 1 \\
\hline 6 & 2.25 & 1 & 0.9 \\
\hline 7 & 2.75 & 1 & 0.9 \\
\hline 8 & 2.25 & 1 & 1.1 \\
\hline 9 & 2.75 & 1 & 1.1 \\
\hline 10 & 2.5 & 0.9 & 0.9 \\
\hline 11 & 2.5 & 1.1 & 0.9 \\
\hline 12 & 2.5 & 0.9 & 1.1 \\
\hline 13 & 2.5 & 1.1 & 1.1 \\
\hline
\end{tabular}

Table 3. Material properties of Aluminum 6063-T5

\begin{tabular}{|l|l|}
\hline Mass $\left(\mathrm{kg} / \mathrm{m}^{3}\right)$ & 2700 \\
\hline Elastic modulus (MPa) & 69000 \\
\hline Poisson ratio & 0.33 \\
\hline Yield strength(MPa) & 180 \\
\hline Tangent modulus(MPa) & 580 \\
\hline
\end{tabular}




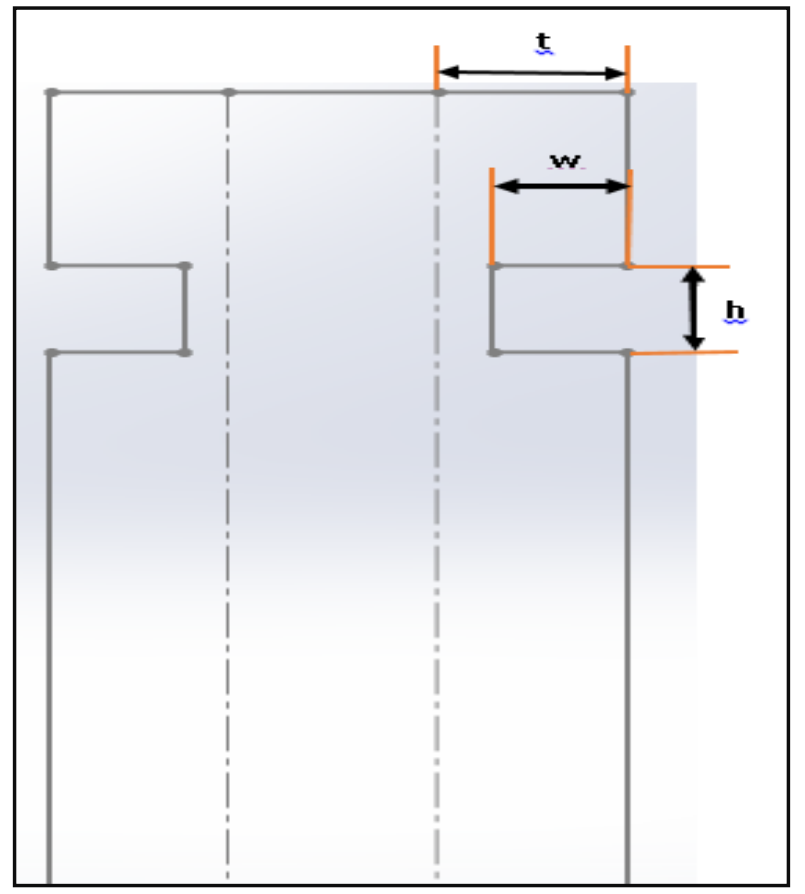

Fig. 1. Design parameters of crash box in twodimension

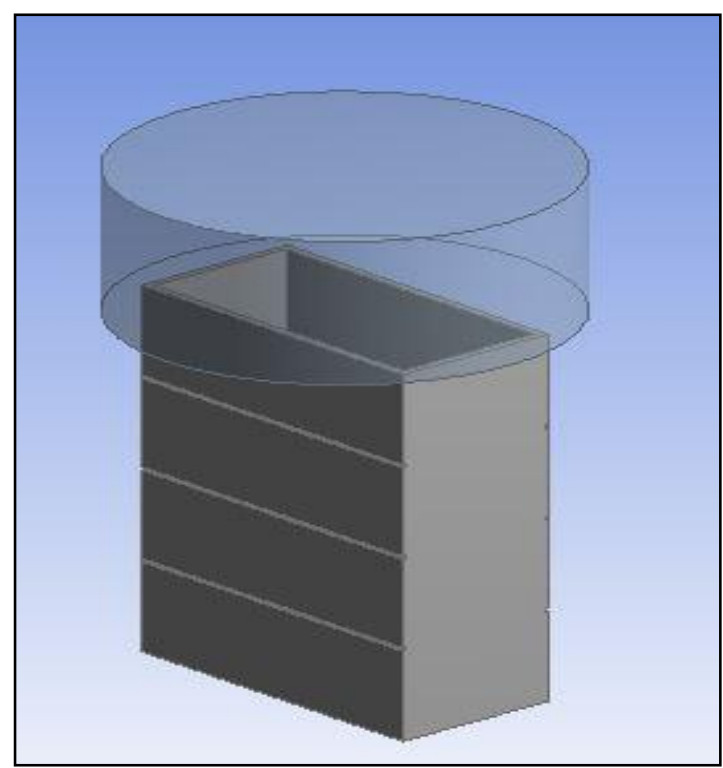

Fig. 2. Section of crash box model

Crash box with length $130 \mathrm{~mm}$ were selected and deformation of crash box and energy absorbing due to frontal load simulation is observed. The impactor set as a frontal axial load collides to crash box with velocity of $7670 \mathrm{~mm} / \mathrm{s}$ along axial load direction. The simulation starting from the initial condition where compactor and crash box set in touch. The impactor modelled as rigid while the crash box set as an elastic body.

\section{Results and Discussions}

Based on the computer simulation, it can be determined energy absorption for each model as shown in the Table 4.

Table 4. Computer simulation results data for energy absorption

\begin{tabular}{|c|c|c|c|l|}
\hline Model - & $\begin{array}{l}\text { Thickness } \\
(\mathrm{mm})\end{array}$ & $\begin{array}{l}\text { Width } \\
(\mathrm{mm})\end{array}$ & $\begin{array}{l}\text { Height } \\
(\mathrm{mm})\end{array}$ & $\begin{array}{l}\text { Energy } \\
\text { Absorption } \\
(\mathrm{mJ})\end{array}$ \\
\hline 1 & 2.5 & 1 & 1 & 3318244 \\
\hline 2 & 2.25 & 0.9 & 1 & 2758632 \\
\hline 3 & 2.75 & 0.9 & 1 & 3912218 \\
\hline 4 & 2.25 & 1.1 & 1 & 2713259 \\
\hline 5 & 2.75 & 1.1 & 1 & 3985469 \\
\hline 6 & 2.25 & 1 & 0.9 & 2728062 \\
\hline 7 & 2.75 & 1 & 0.9 & 4075504 \\
\hline 8 & 2.25 & 1 & 1.1 & 2753346 \\
\hline 9 & 2.75 & 1 & 1.1 & 3909466 \\
\hline 10 & 2.5 & 0.9 & 0.9 & 3325330 \\
\hline 11 & 2.5 & 1.1 & 0.9 & 3312216 \\
\hline 12 & 2.5 & 0.9 & 1.1 & 3357237 \\
\hline 13 & 2.5 & 1.1 & 1.1 & 3318933 \\
\hline
\end{tabular}

It can be shown that the highest energy absorption occurred at model 7 which is $4075504 \mathrm{~mJ}$. Meanwhile, the lowest energy absorption occurred at model 4 which is $2713259 \mathrm{~mJ}$. Based on the comparison between model 4 and 7 its shows that the thickness factor contributing in energy absorption difference. The thickness for model 7 is higher compared to model 4 which is $2.75 \mathrm{~mm}$. It can be concluded that the higher the thickness, the higher the energy absorption. If the thickness bigger the stiffness also will increase where the crush box can withstand more force. In previous study, it can be stated that thickness place an important role to determine the energy absorption of crash box [8]. 
Based on the Fig. 3, it can be shown that comparison between 8 models with height and width is set as constant. Model 2 and 3 have different thickness but the height and width are constant. Based on comparison these models, it can be concluded that the higher the width, the higher the energy absorption. This phenomenon is occurred due to increase in width causes the stiffness of the crash box. It connected to crash box ability to deform during crash force, therefore more energy absorption will occur.

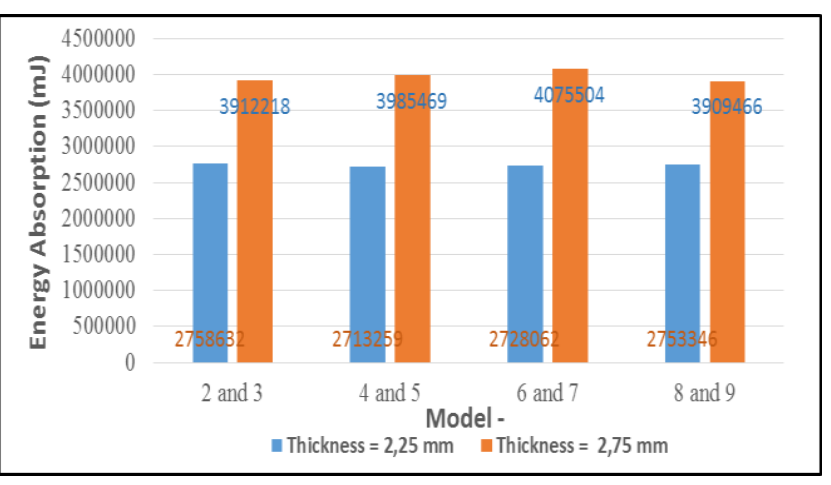

Fig. 3 shows thickness parameter towards energy absorption

Based on the Fig. 4, the 8 model with different width were compared, but the height and thickness were kept constant. Based on the results, it can be concluded that the higher the width, the lower the energy absorption. This is because as theoretically when width increase, the moment of inertia also will increase which causes the energy absorption decrease based on equation (1) and (2).

$$
\begin{aligned}
& \mathrm{U}=\int_{0}^{L}\left(\frac{T^{2}}{2 G J}\right) d x \\
& I=K m\left(\Delta r^{2}\right) \ldots
\end{aligned}
$$

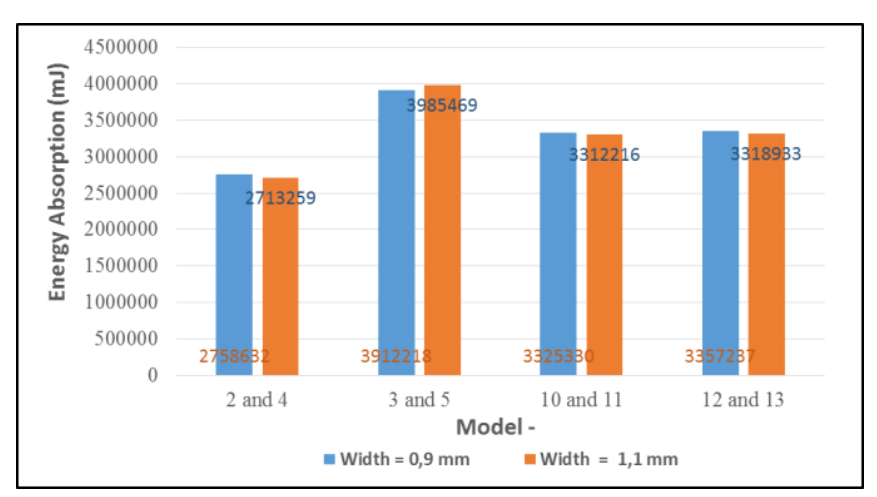

Fig. 4. Effect width parameter towards energy absorption

Fig. 5 shows comparison between 8 model with different height, but width and thickness $s$ set as constant. Based on comparison these models, it can be concluded that the higher the height, the higher the energy absorption. The height increase, the ability of the crash box to deform will increase. therefore higher energy absorption is followed.

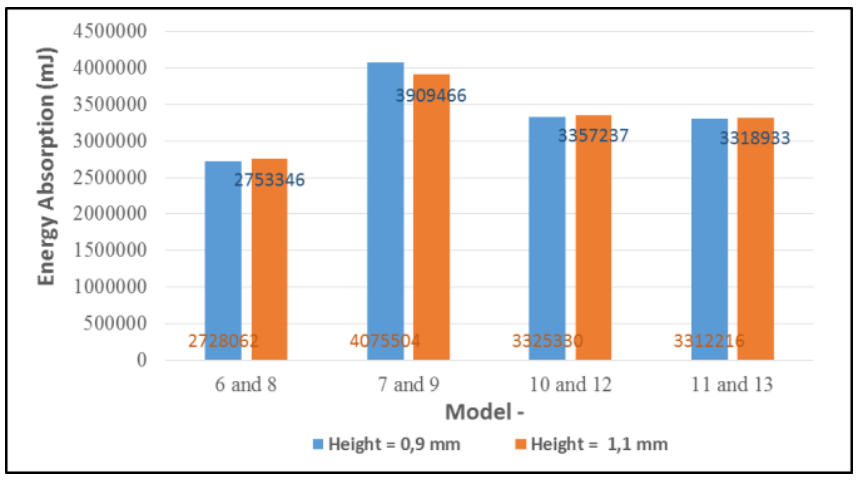

Fig. 5. Effect thickness parameter towards energy absorption

Optimization condition of crash box with response surface methodology provide three candidate point of crash box as shown in the Table 5.

\begin{tabular}{|c|c|c|c|}
\hline & $\begin{array}{c}\text { Candidate } \\
\text { Point 1 }\end{array}$ & $\begin{array}{c}\text { Candidate } \\
\text { Point 2 }\end{array}$ & $\begin{array}{c}\text { Candidate } \\
\text { Point 3 }\end{array}$ \\
\hline $\begin{array}{c}\text { Thickness } \\
(\mathrm{mm})\end{array}$ & 2.75 & 2.75 & 2.75 \\
\hline $\begin{array}{c}\text { Width } \\
(\mathrm{mm})\end{array}$ & 1.1 & 0.9 & 1.1 \\
\hline $\begin{array}{c}\text { Height } \\
(\mathrm{mm})\end{array}$ & 0.9 & 0.9 & 1.1 \\
\hline $\begin{array}{c}\text { Energy } \\
\text { Absorption } \\
(\mathrm{mJ})\end{array}$ & 4084771.075 & 3985219.192 & 3909562.411 \\
\hline
\end{tabular}

Table 5 shows three candidate of design of crash box with optimum condition. Candidate point 1 chosen because the energy absorption is higher compared to candidate point 2 and candidate point 3 . These condition is supported by graphic three dimensional of influence of thickness $(t)$ and width (w) of crash box towards energy absorptions (Fig. 6) and influence of thickness ( $\mathrm{t}$ ) and height (h) of crash box towards energy absorptions (Fig. 7).

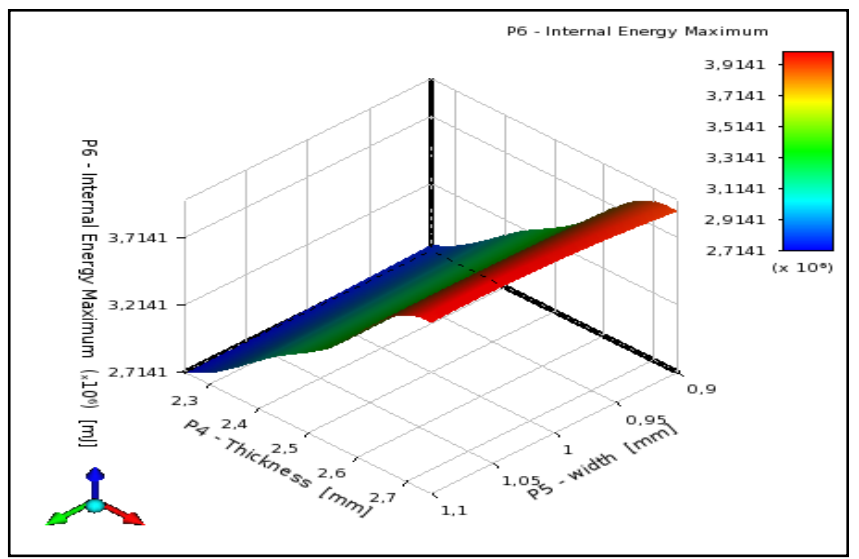

Fig. 6. Three Dimensional of response surface on influence of thickness $(t)$ and width $(w)$ of crash box towards energy absorptions. 


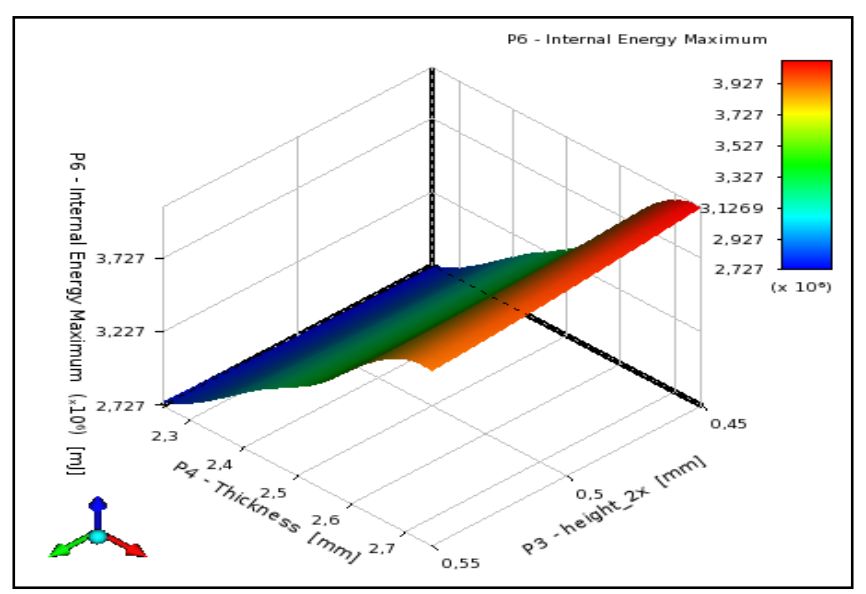

Fig. 7. Three Dimensional of response surface on influence of thickness (t) and height ( $h$ ) of crash box towards energy absorptions.

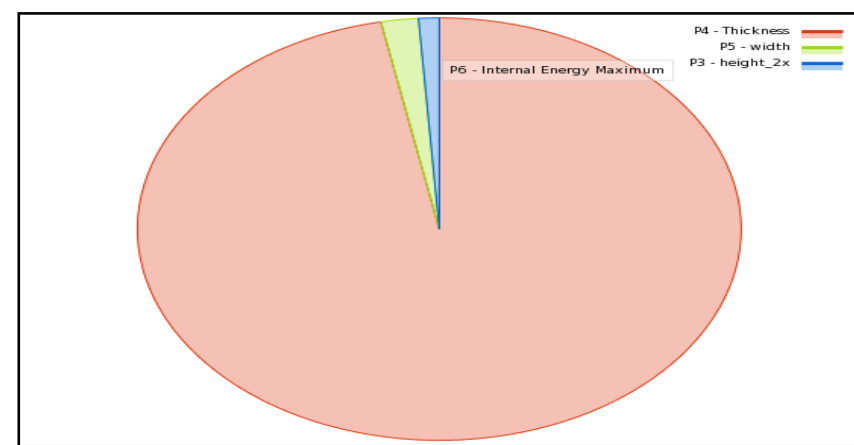

Fig. 8. Influence of input parameter towards output parameter

Based on the Fig. 8, it can be explained that thickness variable is the most influenced compared to width and height.

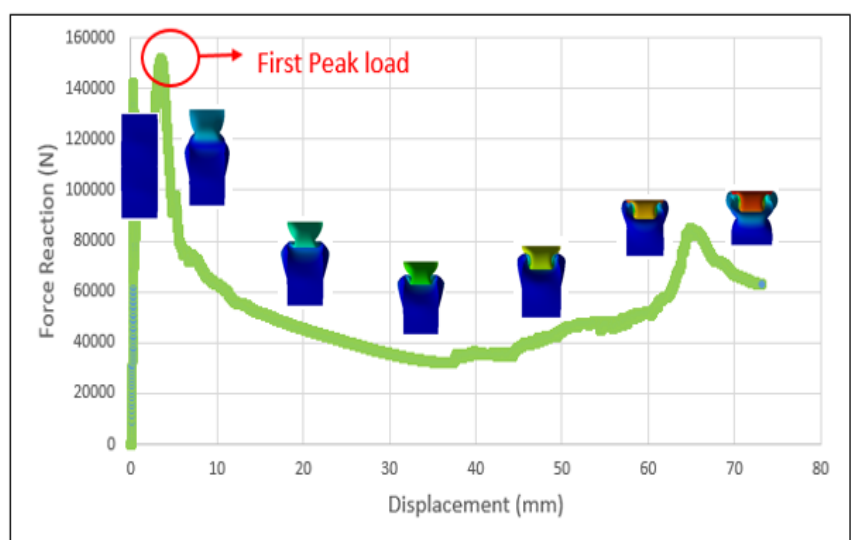

Fig. 9. Graphic displacement towards force reaction in optimum model.

Based on the results, two folding's is occurred in this deformation process. First folding in deformation process require largest force as seen in the Fig. 9. (it called first peak load). First peak load occurs due to the high force reaction [7]. Because more force and longer time needed to make the first folding to occur as lower peak load will help the crush box to deform easily and higher energy will absorbed.

\section{Conclusion}

Optimization of initial folding square sections successfully proposed with largest high energy absorption can be achieved. Three parameters thickness $(t)$, width $(w)$ and height $(h)$ were tested and thickness is the most influence parameter in the deformation of the crash box. A new design scheme of crash box satisfies the demands of improve and maximise the thickness for better energy absorption performance.

\section{Reference}

[1] T. A. Ã, A. Tomiyama, W. Araki, and A. Yamaji, "Energy absorption of a thin-walled cylinder with ribs subjected to axial impact," vol. 35, pp. 65-79, 2008.

[2] H. S. Türkmen, Z. Mecito, N. Uluda, and E. Õ. Alt, "A numerical and experimental study on the impact behavior of box structures," vol. 10, pp. 1736-1741, 2011.

[3] L. Ying, X. Zhao, M. Dai, S. Zhang, and P. Hu, "International Journal of Impact Engineering Crashworthiness design of quenched boron steel thin-walled structures with functionally graded strength," Int. J. Impact Eng., vol. 95, pp. 72-88, 2016.

[4] K. Vinayagar and A. S. Kumar, "Crashworthiness analysis of double section bi-tubular thin-walled structures," Thin Walled Struct., vol. 112, no. January, pp. 184-193, 2017.

[5] A. Ta, E. Acar, M. A. Güler, and Ü. K, "ThinWalled Structures Optimum crashworthiness design of tapered thin-walled tubes with lateral circular cutouts," vol. 107, pp. 543-553, 2016.

[6] Choiron M. A., Sudjito, and Nafisah A. H., "Crash energy absorption of two-segment crash box with holes under frontal load", AIP Conference Proceedings 1717, 050009 (2016); doi: $10.1063 / 1.4943484$

[7] H. Zarei, M. Kro, and H. Albertsen, "An experimental and numerical crashworthiness investigation of thermoplastic composite crash boxes," vol. 85, pp. 245-257, 2008.

[8] S. Ebrahimi and N. Vahdatazad, "Thin-Walled Structures Multiobjective optimization and sensitivity analysis of honeycomb sandwich cylindrical columns under axial crushing loads," Thin Walled Struct., vol. 88, pp. 90-104, 


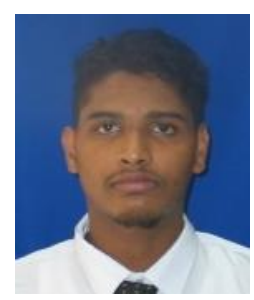

M Yoggaraj Muthusamy is final year of University Tun Hussein Onn Malaysia (UTHM), bachelor degree in mechanical engineering with honours. He finished is diploma in mechanical engineering 20102013 and he worked as inspection officer in ASM technology Singapore for one year before further his studies to bachelor degree.

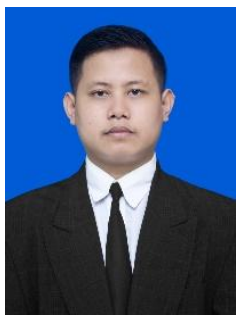

Kamaruddin menyelesaikan studi program sarjana di Jurusan Teknik Mesin Universitas Brawijaya dari tahun 2013 sampai 2017. la menyelesaikan studi program sarjana dengan topik penelitian Optimasi Parameter Desain Beads Crash Box Dengan Response Surface Methodology Untuk Peningkatan Specific Energy Absorption. Area penelitian yang diminati adalah Konstruksi.

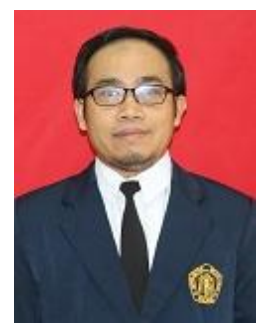

Moch. Agus Choiron, Pada tahun 2011 ia menyelesaikan pendidikan doktoral di Yamaguchi University, Jepang. Saat ini ia bekerja sebagai dosen di jurusan Teknik Mesin Universitas Brawijaya. Bidang Penelitian utama yang digeluti adalah simulasi komputer berbasis aplikasi Finite Element Analysis dan CFD, desain-manufacturing, dan optimasi. 